\title{
Direct Determination of $\mathrm{S}$ and $\mathrm{P}$ at Trace Level in Stainless Steel by CCD-based ICP-AES and EDXRF: A Comparative Study
}

\author{
V.C. Adya, Arijit Sengupta*, S.K. Thulasidas, and V. Natarajan \\ Radiochemistry Division, Bhabha Atomic Research Centre, Mumbai, India
}

\section{INTRODUCTION}

To achieve the desired performance of any material, stringent chemical quality control is one of the prime steps to assure the quality of the material. The presence of different elements can modify the chemical and mechanical properties of the materials. Stainless steel's resistance to corrosion and staining, low maintenance, and familiar lustre make it an ideal material for many applications. It is used for cookware, cutlery, household hardware, surgical instruments, major appliances, industrial equipment, and as an automotive and aerospace structural alloy and construction material in large buildings. Stainless steel (SS) storage tanks and tankers are used for transport, and reaction vessels are used in many industries, including the nuclear industry (1-4). Because SS is such an important industrial material, a stringent quality control is required to achieve its desired performance.

Inductively coupled plasma atomic emission spectrometry (ICPAES), a simultaneous multielemental technique with good analytical performance such as high sensitivity, reproducibility, accuracy, linear dynamic range, and lower detection limits, is commonly employed for the determination of trace metallic constituents in a variety of materials (5-18). Energy dispersive X-ray atomic spectroscopy, being a nondestructive and simultaneously multi-elemental technique (19-22), was employed for the present study for comparison.

\footnotetext{
*Corresponding autbor.

E-mail: arijita@barc.gov.in
}

\begin{abstract}
An inductively coupled plasma atomic emission spectrometry(ICP-AES) based method was developed for the direct determination of phosphorus $(\mathrm{P})$ and sulphur (S) in stainless steel samples. It involved identification of different analytical lines of $\mathrm{P}$ and $\mathrm{S}$ and investigation of their analytical performance including detection limit, sensitivity, linear dynamic range, etc. Iron and chromium, being emission-rich major constituents of stainless steel, their contribution on the trace level determination of $\mathrm{S}$ and $\mathrm{P}$ was also investigated. The energy dispersive X-ray fluorescence (EDXRF) spectroscopic technique was also used for comparative study. The P 177.495-nm and S 180.731-nm lines were found to be suitable for their determination in stainless steel by ICP-AES, whereas the $\mathrm{K} \alpha$ lines were used for the EDXRF study. Based on the developed methodology, five stainless steel samples were analyzed by ICP-AES and EDXRF, and the results were found to be satisfactory. The methodology was also validated by using certified reference materials.
\end{abstract}

In the literature, a variety of metallic constituents have been analyzed by ICP-AES, yet very limited work is available for the determination of non-metals like sulphur (S) and phosphorus (P) (23-30). Using the instrumental advancement of the CCD-based detector systems with a continuous flushing of argon gas, the determination of non-metals is also possible which previously was interfered by atmospheric atomization and ionization.
In the present investigation, different analytical lines for $\mathrm{S}$ and $\mathrm{P}$ were chosen for ICP-AES analysis, whereas the $\mathrm{K} \alpha$ lines were used with energy-dispersive X-ray fluorescence (EDXRF). For both cases, the analytical performance including detection limits, sensitivity, and linear dynamic range was studied. The effect of the spectral interference of iron (Fe) and chromium (Cr), which are major constituents of stainless steel and have line-rich emission spectra, was studied on the trace level determination of $S$ and $\mathrm{P}$. It included identification of the least interfered analytical line, contribution from $\mathrm{Fe}$ and $\mathrm{Cr}$, evaluation of correction factors, and tolerance levels. Based on the above study, using the P 177.495-nm and $S$ 180.731-nm lines in ICP-AES and the $K \alpha$ lines in EDXRF, five real samples of stainless steel were analyzed. The analytical results were found to compare well for both techniques. The method was also validated using certified reference materials and compared with the literature-available values.

\section{EXPERIMENTAL}

\section{ICP-AES Instrumentation}

The analysis was carried out using a Spectro-Arcos inductively coupled plasma atomic emission spectrometer (ICP-AES), equipped with high performing charge couple device (CCD) as the detector and the ICP as a source of excitation (Spectro Analytical Instruments, Kleve, Germany). The optimized operating conditions and instrumental specifications are listed in Table I. The detector system, consisting of linear arrays of the CCD detectors (3648 pixels/ array), thermally stabilized together 
with an optical system, provides the ability to choose alternate analytical lines. The instrument offers low operating costs and uses nopurge UV-Plus sealed gas purification technology.

\section{Standard Solutions and Reagents}

The standard solutions for all of the elements were prepared from CertiPUR ${ }^{\circledR}$ ICP multi standard solutions (E-Merck, Darmstadt, Germany). Suprapure ${ }^{\circledR} \mathrm{HNO}_{3}$ (E-Merck, Darmstadt, Germany), and Milli-Q ${ }^{\circledR}$ quartz double-distilled water (Millipore Corporation, USA). Multi-point standardization was carried out for establishing the calibration curves. For sensitivity and detection limits, 10 replicate measurements were carried out, while for the analysis of the samples, five replicate measurements were made.

\section{EDXRF}

For the present work, a Jordan Valley Ex-3600 M EDXRF spectrometer (Staplethorne, Ltd., UK) was used, equipped with a rhodium source and $\mathrm{Si}(\mathrm{Li})$ detector. The elements $S$ and $P$ were determined in aqueous solutions in the concentration range of $0.1-10 \mathrm{mg} / \mathrm{mL}$. About $10 \mathrm{~mL}$ each of the solution was transferred into special plastic cups (25 mm dia.) for XRF analysis. The open bottom portion of the cup was covered with thin polypropylene film fitted with a suitable lock assembly. The measurements were carried out after covering the top portion of the cup with a plastic lid. Synthetic solution standards containing individually $\mathrm{P}$ and $\mathrm{S}$ at 0.1-10000 $\mu \mathrm{g} / \mathrm{mL}$ were prepared by dissolving $\mathrm{Na}_{2} \mathrm{~S}_{2} \mathrm{O}_{3} \cdot 5 \mathrm{H}_{2} \mathrm{O}$ and $\mathrm{Na}_{4} \mathrm{P}_{2} \mathrm{O}_{7} \cdot 10 \mathrm{H}_{2} \mathrm{O}$, respectively, in quartz double-distilled water and appropriate dilutions. Using the

TABLE I

ICP-AES Specifications and Operating Conditions

\begin{tabular}{ll}
\hline Instrumental Specifications & \\
\hline Optical design & Paschen-Runge mounting, Circular design \\
Focal length & $750 \mathrm{~mm}$ \\
Grating & Holographic \\
Groove density & 1800 grooves $/ \mathrm{mm}(1), 3600$ grooves/mm (2) \\
Wavelength range & $130-800 \mathrm{~nm}$ \\
Entrance slit width & 15 microns \\
Resolution (FWHM) & $0.01 \mathrm{~nm}$ from $130-450 \mathrm{~nm}$ \\
& $0.02 \mathrm{~nm}$ from $450-800 \mathrm{~nm}$ \\
Thermal regulation & Controlled to $30 \pm 1{ }^{\circ} \mathrm{C}$ \\
Frequency & $27.12 \mathrm{MHz}$ \\
Pump & Dual channel peristaltic pump \\
Detector & Linear arrays of CCD (3648 pixels/array) \\
Nebulizer & Cross-flow \\
ICP-torch & Radial viewing \\
Operating condition & \\
Coolant flow & $16 \mathrm{~L} / \mathrm{min}$ \\
Auxiliary flow & $0.6 \mathrm{~L} / \mathrm{min}$ \\
Total time of measurement & $28 \mathrm{~s}$ \\
Pump speed & $30 \mathrm{rpm}$ \\
RF power output & $1.2 \mathrm{~kW}$ \\
Input power & $230 \mathrm{~V}$ AC \\
\hline
\end{tabular}

highest standards of the analytes, the optimum conditions for their determination were calculated using the following equation: $\mathrm{P}-\mathrm{K} \alpha \mathrm{X}$-ray $(2.01 \mathrm{keV}) / \mathrm{no}$ filter $/ 7 \mathrm{kV} /$ $600 \mu \mathrm{A} / 150$ sec and $\mathrm{S}-\mathrm{K} \alpha \mathrm{X}$-rays $(2.3 \mathrm{keV}) /$ no filter $/ 10 \mathrm{kV} / 400 \mu \mathrm{A} / 100$ sec.

Since $\mathrm{Fe}$ and $\mathrm{Cr}$ are emission-rich matrix elements, their presence in stainless steel interferes in the determination of $\mathrm{S}$ and $\mathrm{P}$ at trace levels. Therefore, a series of SpecPure ${ }^{\circledR}$ iron and chromium solutions were fed to the plasma to establish their contribution and correction factors, if any.

Amounts of 1-g stainless steel samples were dissolved in concentrated $\mathrm{HCl}$ and $\sim 2 \mathrm{~mL}$ of concentrated $\mathrm{HNO}_{3}$. The excess acid was removed with repeated heating under an IR lamp using $0.5 \mathrm{M} \mathrm{HNO}_{3}$ to reduce the acidity to less than $0.5 \mathrm{M}$, then it was made up to 25 $\mathrm{mL}$ volume with $0.5 \mathrm{M} \mathrm{HNO}_{3}$. These stock solutions were either fed directly into the plasma without any chemical separation for ICPAES analysis or used for EDXRF analysis.

\section{RESULTS AND DISCUSSIONS}

\section{ICP-AES Determination of $P$ and $S$}

Four different analytical lines of P (177.495 nm, $178.287 \mathrm{~nm}$, $213.618 \mathrm{~nm}$, and $214.914 \mathrm{~nm}$ ) were identified for the present investigation, and their calibration curves were established (Figure 1). Though the P 177.495-nm, 178.287-nm, and 213.618-nm lines showed similar detection limits, the most sensitive line was found to be $P 177.495 \mathrm{~nm}$. Fortunately, the P 177.495-nm line showed larger linear dynamic range for the calibration curves which clearly revealed that on the basis of analytical performance, this line $(177.495 \mathrm{~nm})$ is the best line for the present investigation. 


\section{Atomic Apectroscopy \\ $\bigcup$ Vol. 37(1), Jan./Feb. 2016}

For the present investigation, the S 182.034-nm and 180.731-nm analytical lines were chosen. Though both lines showed good analytical performance, the S 182.034-nm line was found to be the better line with a detection limit of $0.01 \mathrm{mg} / \mathrm{L}$, sensitivity of $2.2 \times 10^{2}$ counts/ $\mathrm{mg} / \mathrm{L}$, and a linear dynamic range up to $5000 \mathrm{mg} / \mathrm{L}$ (Table II). Figure 2 represents the calibration curves for both analytical lines of $S$.

A series of synthetic samples were prepared for the determination of $\mathrm{S}$ and $\mathrm{P}$ in the concentration range of $0.1-1000 \mathrm{~g} / \mathrm{L}$. The analytical results are summarized in Table III and found to be satisfactory.

The overall standard deviation for the determination was less than 3\%.

\section{EDXRF Determination of $P$ and $S$}

The $\mathrm{K} \alpha$ lines were chosen for both $\mathrm{S}$ and $\mathrm{P}$ for their determination by EDXRF. The calibration curves were established for both lines and are shown in Figures 3 and 4 , respectively. The detection limits were $0.55 \mathrm{mg} / \mathrm{L}$ and 0.30 $\mathrm{mg} / \mathrm{L}$ for $\mathrm{P}$ and $\mathrm{S}$, respectively, while the sensitivity values were $10 \mathrm{cps} / \mathrm{mg} / \mathrm{L}$ and $47 \mathrm{cps} / \mathrm{mg} / \mathrm{L}$, respectively. Both lines had a large linear dynamic range of the calibration curves of up to $5000 \mathrm{mg} / \mathrm{L}$.
TABLE II

Analytical Performance of Different Emission Lines of S and P

\begin{tabular}{ccccc}
\hline \multirow{5}{*}{ Element } & $\begin{array}{c}\text { Wavelength } \\
(\mathrm{nm})\end{array}$ & $\begin{array}{c}\text { D.L. } \\
(\mathrm{mg} / \mathrm{L})\end{array}$ & $\begin{array}{c}\text { Sensitivity } \\
(\mathrm{cps} / \mathrm{mg} / \mathrm{L})\end{array}$ & $\begin{array}{c}\text { Linear Dynamic } \\
\text { Range }(\mathrm{mg} / \mathrm{L})\end{array}$ \\
\hline $\mathrm{P}$ & 177.495 & 0.01 & $1.21 \mathrm{E}+04$ & $0.01-5000$ \\
& 178.287 & 0.01 & $8.57 \mathrm{E}+00$ & $0.01-1000$ \\
& 213.618 & 0.008 & $6.08 \mathrm{E}+00$ & $0.008-2000$ \\
& 214.914 & 0.06 & $8.69 \mathrm{E}+03$ & $0.06-2000$ \\
\hline $\mathrm{S}$ & 180.731 & 0.02 & $1.68 \mathrm{E}+02$ & $0.02-5000$ \\
& 182.034 & 0.01 & $2.19 \mathrm{E}+02$ & $0.01-5000$ \\
\hline $\mathrm{P}$ & $\mathrm{K} \alpha$ & 0.55 & $\mathrm{EDXRF}$ & $0.55-5000$ \\
$\mathrm{~S}$ & $\mathrm{~K} \alpha$ & 0.30 & 47 & $0.3-5000$ \\
\hline
\end{tabular}

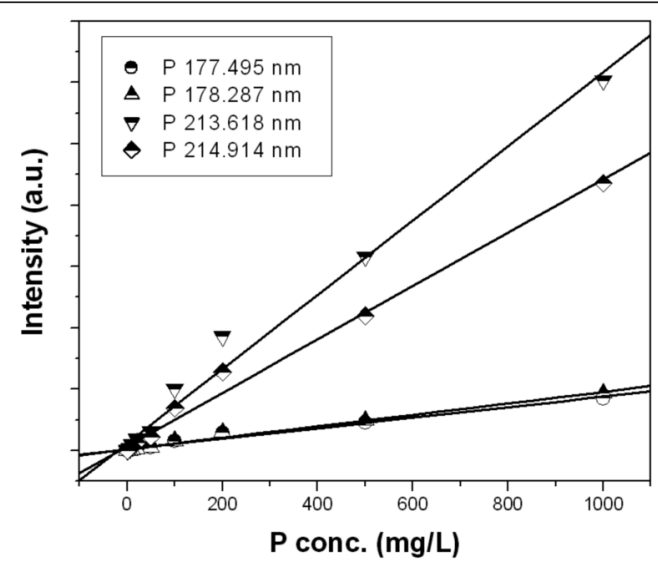

Fig. 1. Calibration curves for different analytical lines of P by ICP-AES.

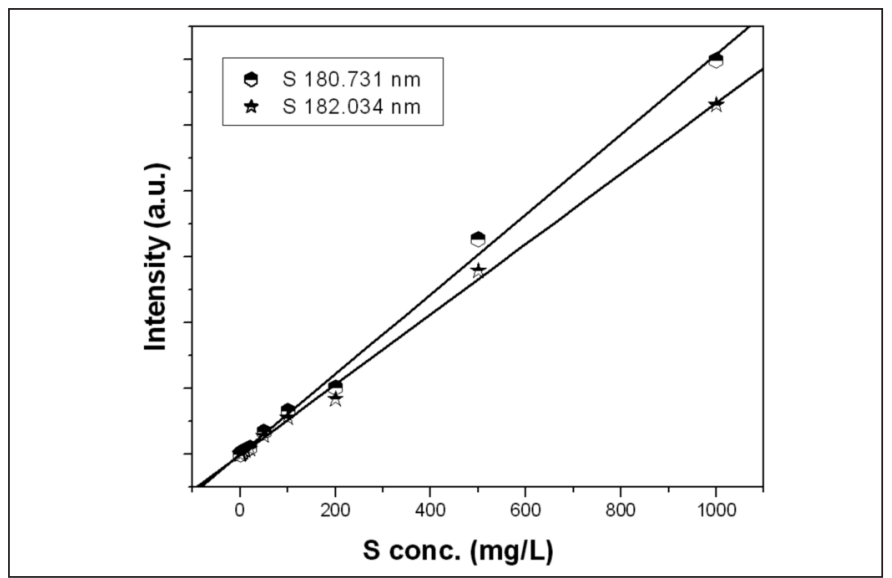

Fig. 2. Calibration curves for different analytical lines of $S$ by ICP-AES.

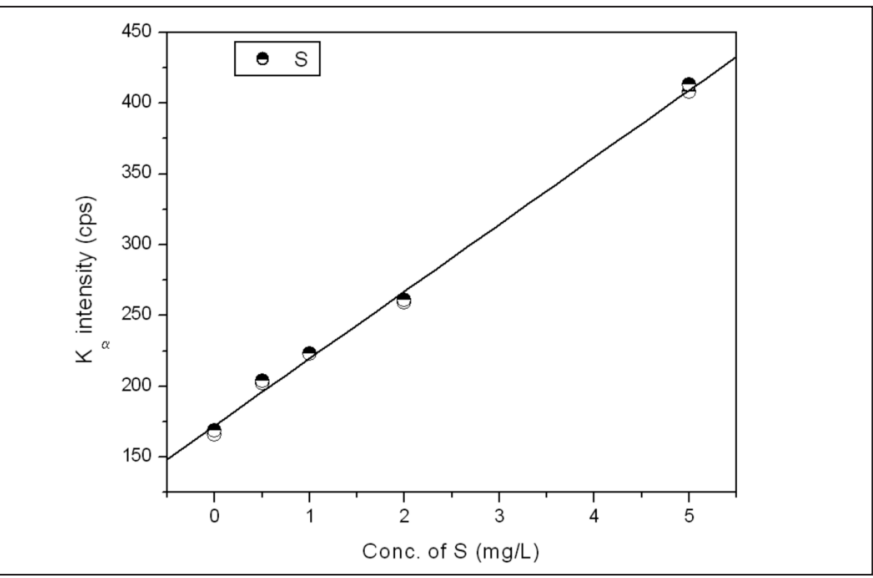

Fig. 3. Calibration curves for $S$ by EDXRF. 
The analytical performance of these lines is summarized in Table II, while the analytical results of the synthetic samples are listed in Table III. The results were found to be satisfactory.

The overall detection limits for $S$ and $P$ were found to be better for ICP-AES than for EDXRF. This fact revealed that for low-level determinations, using ICP-AES is better than EDXRF.

\section{Spectral Interference of Fe and Cr on $P$ and $S$ by ICP-AES}

The elements Fe and $\mathrm{Cr}$ are the main constituents of stainless steel which have line-rich emission spectra. Therefore, to determine $\mathrm{P}$ and $\mathrm{S}$ in a stainless steel matrix, they either have to be separated from the emission-rich matrix elements or suitable correction factors have to be employed to take care of the spectral interference of $\mathrm{Fe}$ and $\mathrm{Cr}$. In the present investigation, the contribution from $\mathrm{Fe}$ and $\mathrm{Cr}$ on the different analytical lines of $\mathrm{P}$ and $\mathrm{S}$ were studied. The contribution of $\mathrm{Fe}$ and $\mathrm{Cr}$ was found to vary linearly with an increase in their concentrations. Based on the linear relationship, suitable correction factors were evaluated. It was observed that the P 177.485-nm and $178.287-\mathrm{nm}$ analytical lines were not interfered by $\mathrm{Fe}$ and $\mathrm{Cr}$, while the P 213.618-nm and $214.914 \mathrm{~nm}$-lines were appreciably interfered by both elements. In case of S, the 180.731-nm line was not interfered by Fe, while the 182.034-nm line showed moderate interference from Fe. Though both lines of S $(180.731 \mathrm{~nm}$ and 182.034 $\mathrm{nm}$ ) were interfered by $\mathrm{Cr}$, the extent of interference was much less for the 180.731-nm line. Based on this study, the P 177.495-nm and 178.287-nm lines with no spectral interference were suitable for $\mathrm{P}$ determination in the presence of $\mathrm{Fe}$ and Cr. The S 180.731-nm line was found to be suitable in the presence of Fe with no spectral interference, while in the presence of $\mathrm{Cr}$, the tolerance level was $500 \mathrm{mg} / \mathrm{L}$ of $\mathrm{Cr}$. Table IV summarizes the effect of $\mathrm{Fe}$ and $\mathrm{Cr}$ on the determination of $\mathrm{S}$ and $\mathrm{P}$, including identification of the most suitable line, correction factors, tolerance level, etc.

\section{Comparison of Results in the Determination of $S$ and $P$ by ICP-AES and EDXRF}

Five different stainless steel samples were used for the determination of $\mathrm{S}$ and $\mathrm{P}$, both by ICP-AES and EDXRF. The P 177.495-nm and $S$ 180.731-nm lines were used in ICP-AES, and the K $\alpha$ lines of the corresponding elements were used in EDXRF. For the S determination, the values were corrected for spectral interference of $\mathrm{Cr}$, while no corrections were necessary for the other cases. Both techniques were found to compare well, and the analytical results shown in Table $\mathrm{V}$ were found to be satisfactory.

\section{Validation of the Methodology by Analyzing Certified Reference Materials}

The method was validated by analyzing certified reference materials (BCS 451 Carbon Steel and BCS 404 Low Alloy Steel (Bureau of Analysed Samples, Ltd., UK) and IRSIL 282-1 Higly Alloy Steel (Bun-

TABLE III

Analysis of S and P in Synthetic Samples by ICP-AES and EDXRF

\begin{tabular}{rrccccc}
\hline \multicolumn{2}{c}{$\begin{array}{c}\text { Elements } \\
(\mathrm{mg} / \mathrm{L})\end{array}$} & ICP-AES & ICP-AES & ICP-AES & ICP-AES & EDXRF \\
\hline & & $177.495 \mathrm{~nm}$ & $178.287 \mathrm{~nm}$ & $213.618 \mathrm{~nm}$ & $214.914 \mathrm{~nm}$ & $\mathrm{~K} \alpha$ \\
\hline $\mathrm{P}$ & 0.1 & $0.11 \pm 0.02$ & $0.10 \pm 0.02$ & $0.09 \pm 0.02$ & $0.09 \pm 0.02$ & BDL $^{\mathrm{a}}$ \\
& 1 & $1.0 \pm 0.2$ & $0.98 \pm 0.05$ & $1.0 \pm 0.1$ & $0.92 \pm 0.08$ & $1.1 \pm 0.2$ \\
10 & $9.7 \pm 0.4$ & $9.9 \pm 0.4$ & $10.3 \pm 0.3$ & $10.2 \pm 0.2$ & $9.9 \pm 0.4$ \\
& 100 & $95 \pm 5$ & $98 \pm 5$ & $102 \pm 5$ & $101 \pm 3$ & $95 \pm 5$ \\
& 1000 & $1010 \pm 5$ & $993 \pm 7$ & $997 \pm 5$ & $1006 \pm 5$ & $998 \pm 3$ \\
\hline $\mathrm{S}$ & 0.1 & $0.09 \pm 0.01$ & $0.11 \pm 0.01$ & $1.0 \pm 0.1$ & $0.09 \pm 0.02$ & BDL $^{\mathrm{a}}$ \\
& 1 & $1.3 \pm 0.2$ & $1.1 \pm 0.05$ & $0.99 \pm 0.1$ & $0.98 \pm 0.08$ & $0.95 \pm 0.2$ \\
& 10 & $10.3 \pm 0.4$ & $9.6 \pm 0.4$ & $9.8 \pm 0.4$ & $10.0 \pm 0.3$ & $9.8 \pm 0.3$ \\
& 100 & $102 \pm 5$ & $101 \pm 5$ & $103 \pm 5$ & $97 \pm 3$ & $99 \pm 5$ \\
1000 & $990 \pm 9$ & $998 \pm 7$ & $1007 \pm 5$ & $997 \pm 5$ & $1008 \pm 3$ \\
\hline
\end{tabular}

${ }^{\mathrm{a}} \mathrm{BDL}=$ below detection limit.

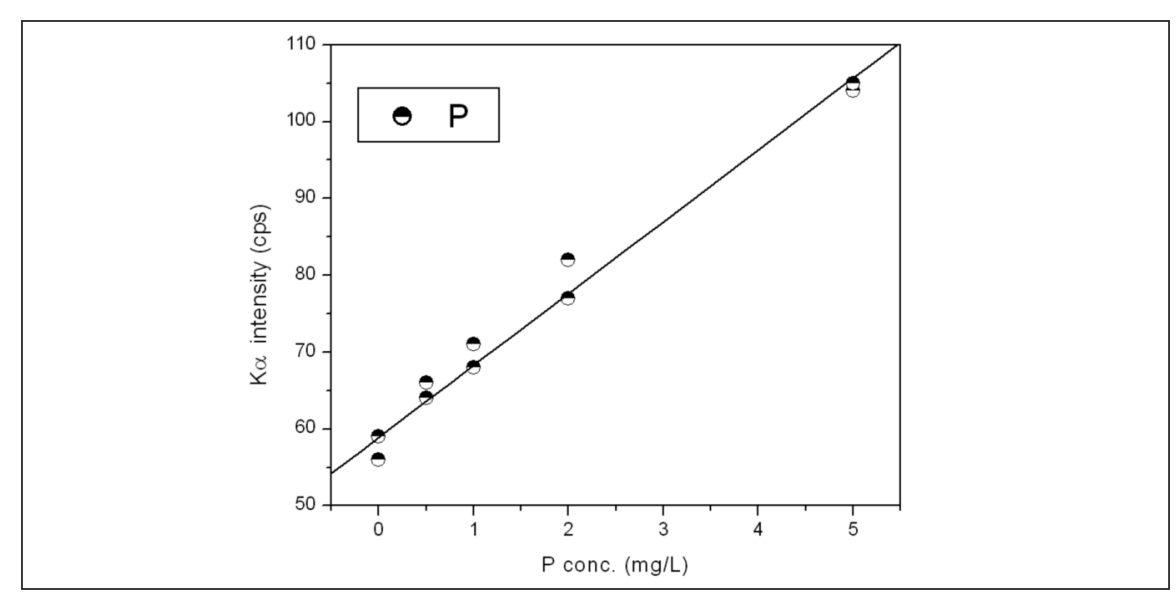

Fig. 4.: Calibration curves for P by EDXRF. 


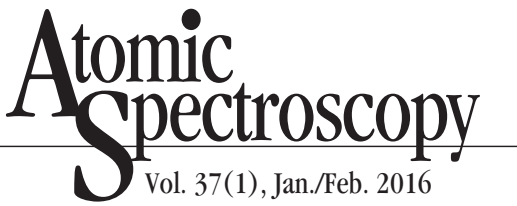

desamt für Materialforschung und -prüfung, Germany). Their compositions were very similar to the samples commonly analyzed with the analytical method. The analytical results obtained in the present case were also compared with those reported in the literature (31). The uncertainty was evaluated experimentally from the relative standard deviation of 15 replicate measurements. The analysis of the certified reference materials is summarized in Table VI.

\section{CONCLUSION}

A comparative study was carried out for the determination of $\mathrm{P}$ and $\mathrm{S}$ in stainless steel samples by ICPAES and EDXRF. The K $\alpha$ lines for $S$ and $P$ were used for EDXRF analysis. Four lines of $\mathrm{P}$ and two lines of $S$ were identified and their analytical performance, including detection limit, sensitivity, and linear dynamic range, were studied. This revealed that the $P$ 177.495-nm and S 180.731-nm lines had the best analytical performance. The $P$ 177.495-nm line was not interfered by $\mathrm{Fe}$ or $\mathrm{Cr}$ which are emission-rich and major constituents of stainless steel. The S 180.731-nm line was also not interfered by Fe, while a minor contribution from $\mathrm{Cr}$ was observed. The results of this study showed that the ICP-AES-based method was better than the EDXRFbased method for low level determination of $\mathrm{S}$ and $\mathrm{P}$, yet both methods gave satisfactory analytical results in the analysis of five stainless steel samples.

\section{ACKNOWLEDGEMENT}

The authors wish to acknowledge the constant support of Dr. A. Goswami, Head, Radiochemistry Division, Bhabha Atomic Research Centre, Mumbai, India.

Received May 6, 2015.
TABLE IV

Contribution From Emission-rich Fe and $\mathrm{Cr}$ on Different Emission Lines Of $S$ and $P$ by ICP-AES

\begin{tabular}{|c|c|c|c|c|c|c|c|}
\hline $\begin{array}{l}\text { Ele- } \\
\text { men }\end{array}$ & $\begin{array}{l}\text { Analytical } \\
\text { Line } \\
(\mathrm{nm})\end{array}$ & $\begin{array}{l}\text { Contribtn. } \\
\text { From } \\
1 \mathrm{mg} / \mathrm{mL} \\
\mathrm{Fe} \\
(\mathrm{mg} / \mathrm{L})\end{array}$ & $\begin{array}{l}\text { Correctn. } \\
\text { Factor } \\
\text { Due to Fe } \\
\text { (mg/L per } \\
\mathrm{mg} / \mathrm{L} \mathrm{Fe})\end{array}$ & $\begin{array}{l}\text { Tolerance } \\
\text { Level of } \\
\text { Fe } \\
(\mathrm{mg} / \mathrm{L})\end{array}$ & $\begin{array}{c}\text { Contribtn. } \\
\text { From } \\
1 \mathrm{mg} / \mathrm{mL} \\
\mathrm{Cr} \\
(\mathrm{mg} / \mathrm{L})\end{array}$ & $\begin{array}{l}\text { Correctn. } \\
\text { Factor } \\
\text { Due to Cr } \\
\text { (mg/L per } \\
\mathrm{mg} / \mathrm{L} \mathrm{Cr} \text { ) }\end{array}$ & $\begin{array}{l}\text { Tolerance } \\
\text { Level of } \\
\mathrm{Cr} \\
(\mathrm{mg} / \mathrm{L})\end{array}$ \\
\hline \multirow[t]{4}{*}{$P$} & 177.495 & $\mathrm{BDL}^{\mathrm{a}}$ & b & b & $\mathrm{BDL}^{\mathrm{a}}$ & b & b \\
\hline & 178.287 & $\mathrm{BDL}^{\mathrm{a}}$ & b & b & $\mathrm{BDL}^{\mathrm{a}}$ & $\mathrm{b}$ & b \\
\hline & 213.618 & 4.2 & 0.0042 & 20 & 13.2 & 0.0132 & 10 \\
\hline & 214.914 & 8.0 & 0.008 & 5 & 9.5 & 0.0095 & 20 \\
\hline \multirow[t]{2}{*}{ S } & 182.034 & 2.5 & 0.0025 & 50 & 3.2 & 0.0032 & 50 \\
\hline & 180.731 & $\mathrm{BDL}^{\mathrm{a}}$ & b & b & 0.08 & 0.00008 & 500 \\
\hline
\end{tabular}

${ }^{\mathrm{a}}$ BDL: below detection limits.

${ }^{\mathrm{b}}$ No spectral interference, therefore not applicable.

TABLE V

Determination of $S$ and $P$ by ICP-AES and EDXRF: A Comparison

\begin{tabular}{ccccc}
\hline $\begin{array}{c}\text { Stainless } \\
\text { Steel }\end{array}$ & $\begin{array}{c}c \\
\text { ICP-AES } \\
(\mathrm{mg} / \mathrm{L})\end{array}$ & $\begin{array}{c}\text { EDXRF } \\
(\mathrm{mg} / \mathrm{L})\end{array}$ & $\begin{array}{c}\text { Sulphur } \\
\text { ICP-AES } \\
(\mathrm{mg} / \mathrm{L})\end{array}$ & $\begin{array}{l}\text { EDXRF } \\
(\mathrm{mg} / \mathrm{L})\end{array}$ \\
\hline SS 1 & $591 \pm 18$ & $575 \pm 28$ & $303 \pm 22$ & $291 \pm 45$ \\
SS2 & $777 \pm 12$ & $783 \pm 14$ & $195 \pm 10$ & $200 \pm 10$ \\
SS3 & $108 \pm 8$ & $115 \pm 8$ & $839 \pm 23$ & $832 \pm 37$ \\
SS4 & $299 \pm 10$ & $289 \pm 12$ & $652 \pm 19$ & $666 \pm 42$ \\
SS5 & $832 \pm 12$ & $830 \pm 32$ & $83 \pm 4$ & $80 \pm 5$ \\
\hline
\end{tabular}

TABLE VI

Analytical Results Obtained From Certified Reference Materials by ICP-AES

\begin{tabular}{|c|c|c|c|c|}
\hline \multirow[t]{2}{*}{ Sample } & \multicolumn{2}{|c|}{ Phosphorus (ppm) } & \multicolumn{2}{|c|}{ Sulphur (ppm) } \\
\hline & $\begin{array}{l}\text { Certified } \\
\text { Value }\end{array}$ & $\begin{array}{l}\text { Experimental } \\
\text { Value (Ref. 31) }\end{array}$ & $\begin{array}{l}\text { Certified } \\
\text { Value }\end{array}$ & $\begin{array}{l}\text { Experimental } \\
\text { Value }\end{array}$ \\
\hline $\begin{array}{l}\text { BCS 451/1 } \\
\text { Carbon Steel }\end{array}$ & 90 & $88 \pm 4(93)$ & 140 & $146 \pm 9$ \\
\hline $\begin{array}{l}\text { BCS } 404 \\
\text { Low Alloy Steel }\end{array}$ & 500 & $511 \pm 25(490)$ & 228 & $220 \pm 11$ \\
\hline $\begin{array}{l}\text { IRSID 282-1 } \\
\text { Highly Alloy Steel }\end{array}$ & 190 & $195 \pm 10(200)$ & 42 & $40 \pm 2$ \\
\hline
\end{tabular}




\section{REFERENCES}

1. M. Anthony Xavior and M. Adithan, J. Materials Processing Technology 209(2), 900 (2009).

2. D.P Davies, P.L Adcock, M Turpin and S. J. Rowen, J. Power Sources 86(1-2), 237 (2000).

3. Han C. Wu and Wei C. Yeh, Internatl. J. of Plasticity 7, 803 (1991).

4. A.M. Azad, O.M. Sreedharan and J.B. Gnanamoorthy, J. Nucl. Mat. 144(1-2), 94 (1987).

5. A. Sengupta, Rajeswari B, R.M. Kadam and S.V. Godbole, At. Spectrosc. 33(2), 48 (2012).

6. A. Sengupta, M.J. Kulkarni and S.V. Godbole, J. Radioanal .Nucl. Chem. 289(3), 961 (2011).

7. A. Sengupta, V.C. Adya and S.V. Godbole, J. Radioanal. Nucl. Chem. 292(3), 1259 (2012).

8. A. Sengupta, V.C. Adya, M. Kumar, S.K. Thulasidas, S.V. Godbole and V.K. Manchanda, At. Spectrosc. 32(2), 49 (2011)

9. Sengupta A, Rajeswari B, Kadam RM, Kshirsagar RJ, Characterization of serpentine: a potential nuclear shielding material, $\mathrm{J}$. Radioanal. Nucl. Chem. 292(2), 903 (2011).

10. A. Sengupta, S.K. Thulasidas and V. Natarajan, J. Radioanal. Nucl. Chem., DOI: 10.1007/s10967-0143679-8 (2014).

11. A. Sengupta, V.C. Adya and S.V. Godbole, J. Radioanal. Nucl. Chem. DOI 10.1007/s10967-013-2520-0 (2013)

12. V.C.Adya, A.Sengupta and S.V. Godbole, At. Spectrosc. 35(1), 25 (2014).

13. A. Sengupta and V.C. Adya, J. Radioanal. Nucl. Chem. 299, 2023 (2014).

14. A. Sengupta and V.C. Adya, At. Spectrosc. 34(6), 207 (2013).

15. A. Sengupta, S.K. Thulasidas and V. Natarajan, At. Spectrosc. 35(5), 213 (2014)

16. A. Sengupta, Y. Airan, S.K. Thulasidas and V. Natarajan, At. Spectrosc. 36(2), 82 (2015).
17. Y. Airan, A. Sengupta, S.K.

Thulasidas and V. Natarajan, At. Spectrosc. 36(1), 15 (2015).

18. A. Sengupta, M.J. Kulkarni, S.V. Godbole, V. Natarajan and P.N. Pathak, At. Spectrosc. 35(2), 60 (2014).

19. R. Sonia, Giancoli Barretoa, Jorge Nozakib, Elisabeth De Oliveirac, Virgilio F. Do Nascimento Filhod, Pedro Henrique A. Aragãoe, Ieda S. Scarminiof and Wagner J. Barreto, Talanta 64 (2), 345 (2004)

20. F.L. Melquiades and C. R. Appoloni, J Radioanal Nucl. Chem. 262(2), 533 (2004)

21. Visnja Orescanina, Anton Katunarb, Ante Kutlec and Vladivoj Valkovicd, J. of Trace and Microprobe Techn. 21(1), DOI: 10.1081/TMA-120017912 (2003)

22. G. Caniglia,I. Calliari,L. Celin and A. M. Tollardo, Nucl. Anal. Methods in the Life Sci. 22, 213 (1994)

23. R. Wennrich, A. Mroczek, K. Dittrich and G. Werner, Fresenius' J. of Anal. Chem. 352(5), 461 (1995)

24. Y. Okamoto, K. Kanda, S. Kishiwada and T. Fujiwara, Appl. Spectrosc. 58(1), 105 (2004)

25. A. Mroczek, G. Werner, R. Wennrich and W. Schrön, Fresenius' J. of Anal. Chem. 361(1), 34 (1998).

26. F. Zhao, S.P. McGrath and A.R. Crosland, Communications in Soil Science and Plant Analysis 25(3-4), 407 (1994).

27. I. Sarudi and J. Kelemen, Fresenius' J. of Anal. Chem. 45(6), 1281 (1998).

28. C.A. Bache and D.J. Lisk, Anal. hem. 39 (7), 786 (1967).

29. P. Bouten and J. Hoste, Anal. Chim. Acta 27, 315 (1962).

30. K.M. Aldous, R.M. Dagnall and T.S. West, Analyst 95, 417 (1970).

31. T. Drglin, Materiali In Tehnologije 39, 4 (2005). 